Biogeosciences Discuss., 7, 7657-7672, 2010

www.biogeosciences-discuss.net/7/7657/2010/

doi:10.5194/bgd-7-7657-2010

(C) Author(s) 2010. CC Attribution 3.0 License.

\title{
Anthropogenic stressors and eutrophication processes as recorded by stable isotopes compositions in coral skeletons
}

O. Levy ${ }^{1,{ }^{*}, \text { M. Rosenfeld }}{ }^{1,{ }^{*}}$, Y. Loya ${ }^{2}$, R. Yam ${ }^{1}$, I. Mizrachi $^{1,2}$, and A. Shemesh ${ }^{1}$

${ }^{1}$ Department of Environmental Sciences, Weizmann Institute of Science Rehovot, Israel ${ }^{2}$ Department of Zoology, Faculty of Life Sciences, Tel Aviv University, Tel Aviv, Israel "now at: The Mina and Everard Goodman Faculty of Life Sciences, Bar-Ilan University, Ramat Gan 52900, Israel

Received: 6 September 2010 - Accepted: 19 September 2010 - Published: 20 October 2010 Correspondence to: O. Levy (levyor@mail.biu.ac.il)

Published by Copernicus Publications on behalf of the European Geosciences Union.

Stable isotopes in corals under eutrophication

O. Levy et al.

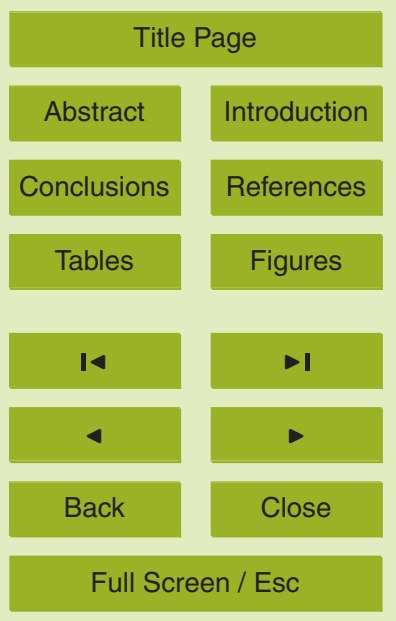

Printer-friendly Version

Interactive Discussion 


\section{Abstract}

The northern Gulf of Aqaba, in the northeastern branch of the Red Sea, is a clear example of humans effecting on the health of fringing reefs. Our results demonstrate the effect of an anthropogenic stressor on the carbon and oxygen stable isotopes com5 positions, namely net pen fish farming with annual fish production of $2.4 \times 10^{6} \mathrm{~kg} \mathrm{yr}^{-1}$. We sampled and studied long coral cores from stressed, remote and intermediate localities and short- term transplanted Porites sp. colonies from the west side of the Gulf of Aqaba to a remote and a polluted sites, respectively. The data shows that mariculture and other human related stressors did not influence the oxygen isotopic signature over a period of two decades. However, the carbon fractionation changed along a geographical gradient and depended on proximity to the source of contamination. We suggest that $\delta^{13} \mathrm{C}$ of coral skeleton is a promising proxy for identifying long term processes of coral growth under high nutrient loads and potential disturbances to the coral reef ecology.

\section{Introduction}

Coral reefs dominated tropical oceans over 200 million years and flourished especially during interglacial periods. Scleractinian (reef building), coral reefs can flourish in the nutrient-poor (Darwin, 1842; Odum and Odum, 1955) environments due to their mutualistic symbiosis with dinoflagellates (Symbiodinium spp.), known as zooxanthellae. Their carbon and energy requirements are met by different species-specific combinations of algal photosynthetic products, as well as by predation on zooplankton, supplemented in some cases by minor contributions of dissolved organic carbon compounds and bacteria (Muscatine et al., 1989). Scleractinia, a major member of phylum Cnidaria, forms the framework of coral reef communities, in which they from massive structures that monopolize coastal zones in tropical seas (Allemand et al., 2004). During the last two decades coral reefs have undergone an increase in various
BGD

$7,7657-7672,2010$

Stable isotopes in corals under eutrophication

O. Levy et al.

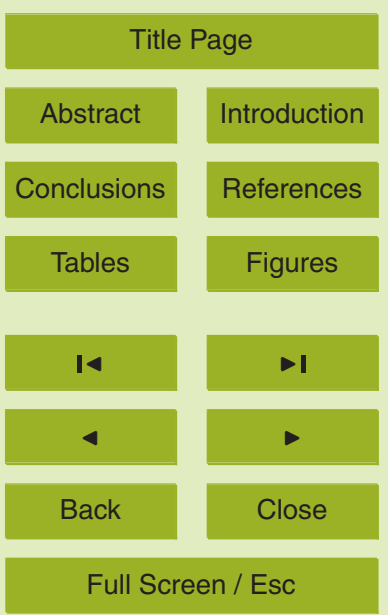

Printer-friendly Version

Interactive Discussion 
anthropogenic environmental disturbances (Goreau et al., 2000). These have placed unprecedented stresses on coral reefs, primarily through declining water quality, pollution, overexploitation, and more recently by changes to the atmospheric concentration of greenhouse gases through ocean warming and acidification (Hoegh-Guldberg et al., 5 2007). On the local scale, pollution by human activities leads mainly to eutrophication and siltation, exposing many fringing and offshore reefs to severe stress (Brown, 1997; Loya, 2007). Corals provide record of the chemical and physical conditions that existed in the local seawater at the time of accretion of their calcium carbonate skeletons (Mcconnaughey, 2003; Allemand et al., 2004; Meibom et al., 2007). Due to their high 10 rate of growth and accretion of solid calcium carbonate, corals serve as an oceanic recorder with enhanced time resolution (monthly to seasonal) (Mcculloch et al., 1999; Cohen et al., 2001; Felis et al., 2003). Coral skeletal variations in stable isotopes, such as oxygen and carbon, reflect surrounding seawater temperatures, evaporation, precipitation, light intensity, and coral metabolic activity but in a complex and non-linear 15 way (Levy et al., 2006; Rosenfeld et al., 2006).

A particularly relevant site for investigating reef health is the rich coral reefs in the Israel port city of Eilat, situated at the northern edge of the Gulf of Aqaba, Red Sea. Although coral ecosystems are usually affected by one or another stress-producing element, the Eilat reefs provide a convenient laboratory for studying damage, for they have been subjected to multiple natural and man-made disturbances.

Although the coral reefs at Eilat (Red Sea, $29^{\circ} \mathrm{N}$ ) are situated near the northern limit of reef building by stony (scleractinian) corals, they are highly diverse (Loya, 1972) and characterized by a high degree of endemism (Fishelson, 1995). They have been exposed to various natural and anthropogenic disturbances (Loya, 2007). The shallow reefs are affected by occasional winter storms that cause large surge (Friedman, 1968), which can dislodge a considerable number of corals (Wielgus and Levy, 2006). Anthropogenic stresses from intensive tourism activity and poor water quality from sewage pollution, flood waters, ballast and bilge water from boat activity and discharges of fuel, oil, detergents, and phosphates have all damaged the reefs. In the last several
BGD

7, 7657-7672, 2010

Stable isotopes in corals under eutrophication

O. Levy et al.

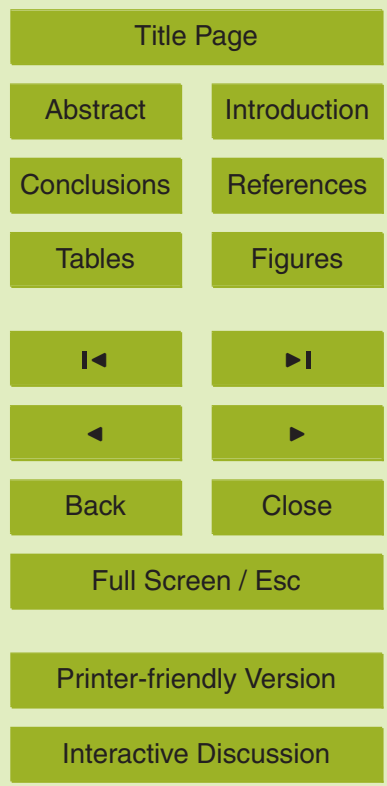


years, water clarity has deteriorated, along with the symbiont photosynthesis and coral calcification (Atkinson et al., 2001). Also, in the last 10 years, mariculture effluents of $2.4 \times 10^{6} \mathrm{~kg} \mathrm{yr}^{-1}$ of in situ net-pen fish cages (mainly Sparus aurata, a non indigenous species in the Gulf of Aqaba (Eilat) were deployed in the northeast part of the Gulf. 5 These facilities discharge organic matter $\left(4 \times 10^{4} \mathrm{~kg}\right.$ of phosphorous and $2.4 \times 10^{5} \mathrm{~kg}$ of nitrogen) and particulate matter into the water column (Loya et al., 2004). The fish farms have "replaced" the urban sewage, which stopped in 1995 because land facilities for urban sewage treatment were developed (Loya et al., 2004). There is a general consensus that Eilat's scleractinian corals have suffered in recent years, characterized 10 by $70 \%$ loss of abundance, over $50 \%$ decrease in coral cover, low rates of larval settlement and recruitment (Ben-Tzvi et al., 2004), a decrease in calcification (Silverman et al., 2004), an increase in coral mortality, macro-algal blooms smothering the corals, and the increasing percentages of corals affected by pathogenic diseases related to continuous eutrophication originating from the fish farming (Loya et al., 2004).

We undertook to measure and compare the isotopic signatures and the growth parameters formed under relatively disturbed and remote conditions of Porites sp. colonies which were transplanted in 2001 in the vicinity of the fish farm cages in the northern tip of the Gulf (high nutrient load, low clarity, high phytoplankton productivity (Genin and Silverman, 2005; Genin and Shaked, 2006, 2007) and on the reef across from the Interuniversity Marine Institute (IUI) "reference site" (relatively remote and undisturbed conditions). Furthermore we also undertook a historic study of gradients in the $\delta^{18} \mathrm{O}$ and $\delta^{13} \mathrm{C}$ isotopic records of corals of the northern part of the Gulf of Aqaba, going from north to south. Long-drilled records from three colonies were examined in order to identify and trace possible environmental stress in the region. This allowed us to obtain, for the first time, the isotopic signature of coral growth under high nutrient loads. The outcome of these environmental and "human affect" influences is of concern to the future of coral reefs found in the north tip of the Red Sea and they may be indicative of future anthropogenic patterns associated with regions which are considered to be under high human impact.
BGD

$7,7657-7672,2010$

Stable isotopes in corals under eutrophication

O. Levy et al.

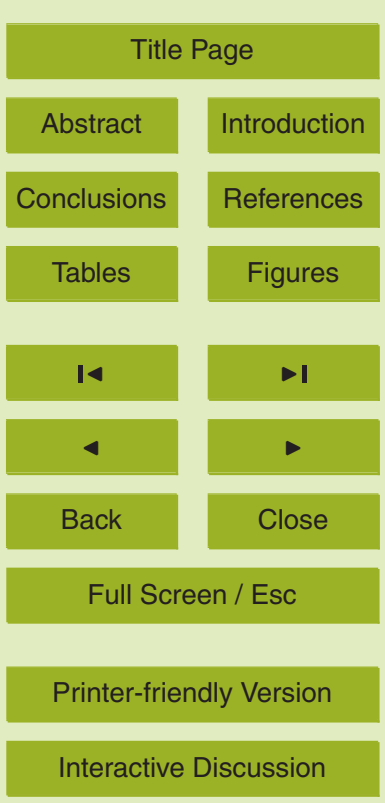




\section{Materials and methods}

In 2001, several single Porites sp. colonies were stained with alizarin red, acclimated and later transplanted from the Navy harbor (see Fig. 1) to the vicinity of the fish farm area and in front of the IUI research station (Rosenfeld et al., 2003). The corals were

5 transplanted $20 \mathrm{~m}$ below the surface in order to preserve their original depth. The Porites corals were monitored every month by scuba diving to determine how well they survived the transplantation procedure. During 2005 five of the transplanted colonies were harvested, two from the IUI and three from the fish farms. The severe flood of winter 2006 killed the remaining corals, which were intended to serve as a long-term monitor of eutrophication. All five corals were analyzed for their isotopic compositions during the years before and after transplantation. Addition set of Porites sp. cores were sampled in order to obtain the modern north-south gradients from the fish farms to Taba, along with corals that were transplanted near the fish farms cages and in IUI ("reference site"). The three large colonies that have been drilled provided 20-25 years of history pattern records. All coral cores were washed; air dried, and sectioned into $7 \mathrm{~mm}$ thick slabs. The cores were $\mathrm{x}$-rayed, with positive prints of the slabs revealing the annual density-banding patterns characteristic of massive corals, such as Porites. The prints were used as a guide for microdrilling along the major axis of growth and later for the chronological ordering, age modeling, of the coral bands (Linsley et al., 1999).

For high-resolution reconstructions, samples of $100-150 \mu \mathrm{g} \mathrm{CaCO}_{3}$ were extracted every $0.6 \mathrm{~mm}$ with a dental drill (Swart, 1983). Because corals grow 8-12 mm per year, this sampling method provides bimonthly-monthly resolution. $\mathrm{CaCO}_{3}$ samples for $\delta^{18} \mathrm{O}$ and $\delta^{13} \mathrm{C}$ analyses were reacted with $100 \%$ orthophosphoric acid and $\mathrm{CO}_{2}$ was measured using a Finnigan GasBench II gas preparation unit connected on line to a Finnigan MAT 252 isotope ratio mass spectrometer. Calibration was maintained by routine analyses of internal and international standards. The long-term precision of our internal laboratory standard is $0.06 \%$ and $0.10 \%$ for carbon and oxygen, respectively. Even-spaced time series (monthly) were obtained by interpolating the raw data using

BGD

7, 7657-7672, 2010

Stable isotopes in corals under eutrophication

O. Levy et al.

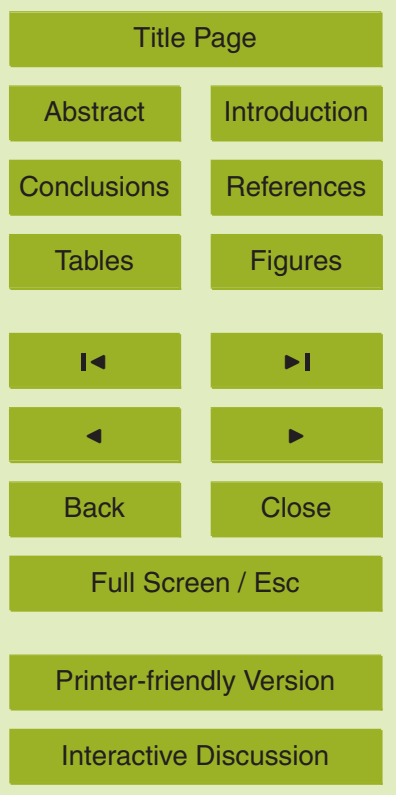

Interactive Discussion 
the Analyseries time series analysis tool (Paillard et al., 1996) from isotopic minima and maxima. Results are reported in per-mill units relative to the international ViennaPeedee Belemnite Limestone Standard (V-PDB). Interpretation and correlation of the data were related to temperature, light, water currents, salinity and nutrient data which are available at high temporal resolution from the long term monitoring program in Eilat, running by the Interuniversity Institute (IUI) which was also acting in this project as the "reference site".

\section{Results}

We have obtained 6-7 years of high-resolution records from each colony. The transplanted colonies at the IUI reference site exhibited no change in their $\delta^{13} \mathrm{C}$ pattern, neither in amplitude nor absolute values (Figs. 2a, b and Fig. 3a, t-test $p>0.05$ ); the annual average growth rate was $9.86 \pm 1.72 \mathrm{~mm} \mathrm{yr}^{-1}$. In contrast, the carbon isotopic measurements of the corals transplanted to the fish cages (FCI, FCII, and FCIII) clearly demonstrated a "high nutrient load" growth phase in the skeletons. There is a marked 15 alteration in the pattern and amplitude of the annual $\delta^{13} \mathrm{C}$ relative to "normal" growth period prior to transplantation (t-test $p<0.05$ ), (Fig. 2c-e, Fig. 3a) although average growth rates did not decline and amounted to $9.94 \pm 3.32 \mathrm{~mm} \mathrm{yr}^{-1}$. Hence, we are able to identify the $\delta^{13} \mathrm{C}$ isotopic signature of a period of high nutrient load. There was no significant alteration of $\delta^{18} \mathrm{O}$ signals of both transplanted groups, IUI and FC, due to 20 transplantation (Fig. 2f, t-test $p>0.05$ ). Overall, all corals isotopic composition show a relatively constant annual water temperature throughout the past $6-7$ years, and they capture the normal annual cycle of sea surface temperature (Fig. 3b). Our measurements are in good agreement with the long term in situ SST measurements carried out at the IUI peer.

25 North-south gradients of three cores drilled from large Porites sp. colonies at a water depth of 5-7 m were used to document the isotopic records characteristic of the last 20-25 years in the Gulf Aqaba. The first core, point A (Fig. 1), is the northernmost site
BGD

$7,7657-7672,2010$

Stable isotopes in corals under eutrophication

O. Levy et al.

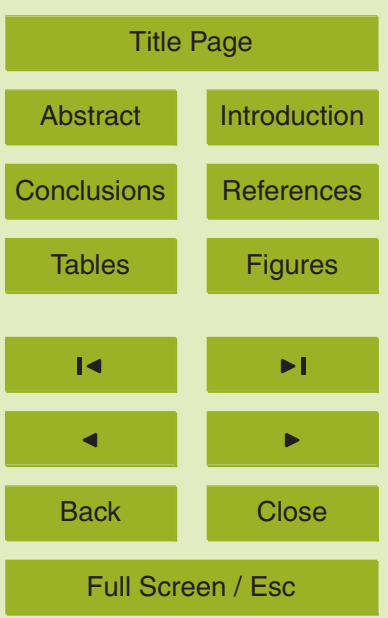

Printer-friendly Version

Interactive Discussion 
where large Porites were identified in the Gulf; the second core was sampled to the south at point A, some $700 \mathrm{~m}$ north of the Navy harbor, near point B (Fig. 1). The third core was taken at the southernmost part of the study site, point $C$, (Fig. 1). Positions of the three cores allowed us to detect the possible influence of the high nutrient load 5 plume that could have originated from the fish cages to the north. We have obtained an average resolution of 15 samples per year after assigning an absolute age to each sample, which allows an accurate reconstruction, with monthly details, of the annual cycles of oxygen and carbon isotopes. The average results of $\delta^{18} \mathrm{O}$ from the three cores does not exhibit significant long-term annual trend, implying that temperature, 10 evaporation and salinity remained constant during the past two decades (Fig. 4a, oneway ANOVA, $p>0.05$ ). The $\delta^{13} \mathrm{C}$ values (Fig. 4b) show significant differences between the south cores, B and $\mathrm{C}$, and the north core $\mathrm{A}$ (one-way ANOVA, $p<0.05$ ). B and $\mathrm{C}$ core samples do not exhibit a long-term trend and the annual variability is very similar over the past 25 years, with annual growth ranging 12.2 and $10.28 \mathrm{~mm} \mathrm{yr}^{-1}$, respectively. This suggests that the physiological parameters of the corals including skeletal growth did not significantly change during this period and that they were probably exposed to the same light levels, nutrient loads, and trophic activity throughout the entire period. In contrast, carbon isotopic record from core $A$, which is the closest site to the fish cages and the northern hotel line, exhibited an annual growth of $9.28 \mathrm{~mm} \mathrm{yr}^{-1}$ 20 (Fig. 4b). Before 1994, the signal is similar to the patterns presented by all other corals. However, after 1994 the signal is characterized by large anomalous annual amplitudes, as well as an overall shift towards heavy $\delta^{13} \mathrm{C}$ values (one-way ANOVA, followed by Tukey HSD test, $p<0.05$ ).

\section{Discussion}

25 The results presented here imply that the carbon signature is more sensitive to environmental stress than the annual changes in the skeletal growth. In fact, this change resembles the pattern in the $\delta^{13} \mathrm{C}$ record of the corals transplanted to the fish-cage

\section{BGD}

7, 7657-7672, 2010

\section{Stable isotopes in corals under eutrophication}

O. Levy et al.

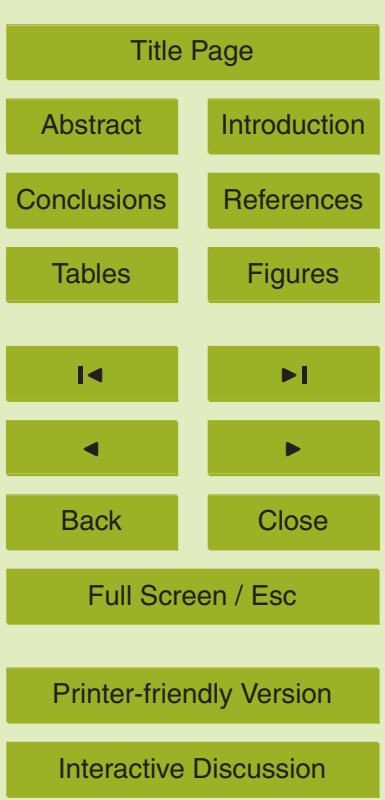


area and is similar to the pattern of high heterotrophy caused by increased levels of zooplankton (Grottoli, 2002). Thus, the corals in the vicinity of the northern part of the Gulf themselves are witnesses to increasingly higher nutrient load and discharge, which is known to have risen rapidly since $1994\left(2 \times 10^{5} \mathrm{~kg} \mathrm{yr}^{-1}\right.$ of fish in 1991 to an5 nual $4.5 \times 10^{5} \mathrm{~kg} \mathrm{yr}^{-1}$ in 1994, Fig. 5) with maximum production of 2400 tons in 2001 (Atkinson et al., 2001). However this influence was not observed in the carbon isotope measurements of the southern cores ( $B$ and $C), \sim 2.5,8 \mathrm{~km}$ south-west to the fish cages. There are two ways of explaining this observation: (a) the excess nutrients from the north are diluted over $2.5 \mathrm{~km}$ to a level that does not affect coral growth at depth of 10 about $7 \mathrm{~m}$ or (b) the excess nutrients move eastward or to the center of the Gulf without reaching coastal areas to the southwest. However, the prevailing winds and the surface current regime do not support eastward diversion of the surface water. Furthermore our study shows unequivocally that Porites sp. colonies were affected at the site close to the fish farming compared to those growing to the southwest, such as sites B, IUI, and $C$. The impact of Gulf eutrophication seems to be local (scale of $2 \mathrm{~km}$ ), but with time chronic nutrient enrichment may affect a larger reef area south of point A. Several years of monthly monitoring light intensity did not reveal any significant change among 8 costal sampling sites along the Israeli coast, including the FC (Genin and Shaked, 2008, Fig. C11). Hence, we rule out the possibility that light may have affected the carbon signals (Grottoli, 2002). Global climatic factors may interact with local stresses to hasten the decline of marine communities and the degradation of coral reefs around the planet; coastal marine eutrophication has drastic consequences on corals reefs, in particular. Therefore using carbon isotopes in coral skeleton will be important in assessing anthropogenic stressors in coral reefs and associated ecosystems, and can be 25 used to distinguish between local and global stresses. In addition, $\delta^{13} \mathrm{C}$ of long coral skeletal records can be used to identify past periods of high nutrient loads.

Acknowledgements. We thank, Irena Brailovsky for helping with sample preparations for carbon measurements. We acknowledge the Marine Laboratory at Eilat for the warm hospitality. This work was funded by the Israeli Science Foundation (ISF) to Aldo Shemesh.

\section{BGD}

$7,7657-7672,2010$

Stable isotopes in corals under eutrophication

O. Levy et al.

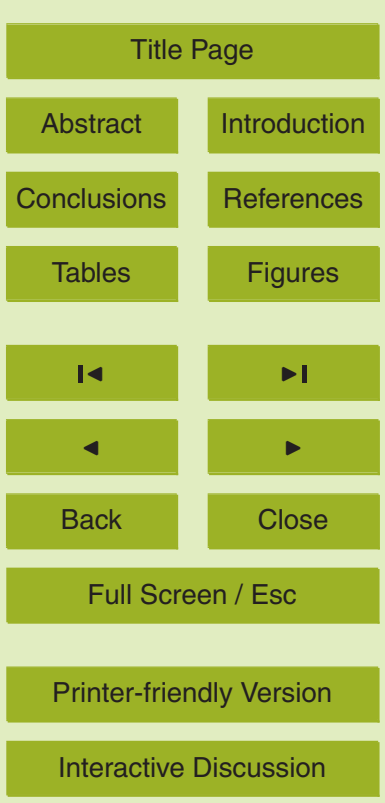




\section{References}

Allemand, D., Ferrier-Pages, C., Furla, P., Houlbreque, F., Puverel, S., Reynaud, S., Tambutte, E., Tambutte, S., and Zoccola, D.: Biomineralisation in reef-building corals: from molecular mechanisms to environmental control, C. R. Palevol, 3, 453-467, 2004.

5 Atkinson, M. J., Birk, B., and Rosenthal, H.: Evaluation of pollution in the Gulf of Eilat, Report for the Israeli Ministries of Infrastructure, Environment and Agriculture, Eilat, Israel, 2001.

Ben-Tzvi, O., Loya, Y., and Abelson, A.: Deterioration Index (DI): a suggested criterion for assessing the health of coral communities, Mar. Pollut. Bull., 48, 954-960, 2004.

Brown, B. E.: Disturbances to reefs in recent times, in: Bireland, C. (Ed.), Life and Death of Coral Reefs, Chapman and Hall, New York, NY, 354-378, 1997.

Cohen, A. L., Layne, G. D., Hart, S. R., and Lobel, P. S.: Kinetic control of skeletal Sr/Ca in a symbiotic coral: implications for the paleotemperature proxy, Paleoceanography, 16, 2026, 2001.

Darwin, C. R.: The Structure and Distribution of Coral Reefs, Smith Elder, London, 1842.

15 Felis, T., Pätzold, J., and Loya, Y.: Mean oxygen-isotope signatures in Porites spp. corals: inter-colony variability and correction for extension-rate effects, Coral Reefs, 22, 328-336, 2003.

Fishelson, L.: Eilat (Gulf of Aqaba) littoral: life on the red line of biodegradation, Israel J. Zool., 41, 43-55, 1995.

20 Friedman, G. M.: Geology and geochemistry of reefs, carbonate sediments, and waters Gulf of Aqaba (Elat) Red Sea, J. Sediment. Petrol., 38, 895-919, 1968.

Genin, A. and Silverman, J.: The Israel National Monitoring Program in the Northern Gulf of Aqaba, Science report for year 2004, Ministry of Environmental Protection, Israel, 2005.

Genin, A. and Shaked, Y.: The Israel National Monitoring Program in the Northern Gulf of

25 Aqaba, Science report for year 2005 (in Hebrew), Ministry of Environmental Protection, Israel, 2006.

Genin, A. and Shaked, Y.: The Israel National Monitoring Program in the Northern Gulf of Aqaba, Science report for year 2006 (in Hebrew), Ministry of Environmental Protection, Israel, 2007.

30 Goreau, T., Mcclanahan, T., Hayes, R., and Strong, A.: Conservation of coral reefs after the 1998 global bleaching event, Conserv. Biol., 14, 5-15, 2000.

Grottoli, A. G.: Effect of light and brine shrimp on skeletal delta C-13 in the Hawaiian coral
BGD

7, 7657-7672, 2010

Stable isotopes in corals under eutrophication

O. Levy et al.

Title Page

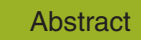

Introduction

Conclusions

References

Tables

Figures

14

$\rightarrow$

4

Back

Close

Full Screen / Esc

Printer-friendly Version

Interactive Discussion 
Porites compressa: a tank experiment, Geochim. Cosmochim. Ac., 66, 1955-1967, 2002.

Hoegh-Guldberg, O., Mumby, P. J., Hooten, A. J., Steneck, R. S., Greenfield, P., Gomez, E., Harvell, C. D., Sale, P. F., Edwards, A. J., Caldeira, K., Knowlton, N., Eakin, C. M., IglesiasPrieto, R., Muthiga, N., Bradbury, R. H., Dubi, A., and Hatziolos, M. E.: Coral reefs under rapid climate change and ocean acidification, Science, 318, 1737-1742, 2007.

Levy, O., Rosenfeld, M., Yam, R., and Shemesh, A.: Heterogeneity of coral skeletons isotopic compositions during the 1998 bleaching event, Limnol. Oceanogr., 51, 1142-1148.

Linsley, B. K., Messier, R. G., and Dunbar, R. B.: Assessing between-colony oxygen isotope variability in the coral Porites lobata at Clipperton Atoll, Coral Reefs, 18, 13-27, 1999.

Loya, Y.: Community structure and species diversity of hermatypic corals at Eilat, Red Sea. Mar. Biol., 13, 100-123, 1972.

Loya, Y.: How to influence environmental decision makers? The case of Eilat (Red Sea) coral reefs, J. Exp. Mar. Biol. Ecol., 344, 35-53, 2007.

Loya, Y., Lubinevsky, H., Rosenfeld, M., and Kramarsky-Winter, E.: Nutrient enrichment caused 15 by in situ fish farms at Eilat, Red Sea is detrimental to coral reproduction, Mar. Pollut. Bull., 49, 344-353, 2004.

McConnaughey, T. A.: Sub-equilibrium oxygen-18 and carbon-13 levels in biological carbonates: carbonate and kinetic models, Coral Reefs, 22, 316-327, 2003.

McConnaughey, T. A., Burdett, J., Whelan, J. F., and Paull, C. K.: Carbon isotopes in biological carbonates: respiration and photosynthesis, Geochim. Cosmochim. Ac., 61, 611-622, 1997.

McCulloch, M. T., Tudhope, A. W., Esat, T. M., Mortimer, G. E., Chappell, J., Pillans, B., Chivas, A. R., and Omura, A.: Coral record of equatorial sea-surface temperatures during the penultimate deglaciation at Huon Peninsula, Science, 283, 202-204, 1999.

Meibom, A., Mostefaoui, S., Cuif, J. P., Dauphin, Y., Houlbreque, F., Dunbar, R., and Constantz, B.: Biological forcing controls the chemistry of reef-building coral skeleton, Geophys. Res. Lett., 34, L02601, doi:10.1029/2006gl028657, 2007.

Muscatine, L., Porter, J. W., and Kaplan, I. R.: Resource partitioning by reef corals as determined from stable isotope composition. $1 . \delta^{13} \mathrm{C}$ of zooxanthellae and animal tissue vs. depth, Mar. Biol., 100, 185-193, 1989.

30 Odum, H. T. and Odum, E. P.: Trophic structure and productivity of windward coral reef community of Eniwetok Atoll, Ecol. Monogr., 25, 291-320, 1955.

Paillard, D., Labeyrie, L., and Yiou, P.: Macintosh program performs time-series analysis, Eos T. Am. Geophys. Un., 77, 379, 1996.
BGD

7, 7657-7672, 2010

\section{Stable isotopes in corals under eutrophication}

O. Levy et al.

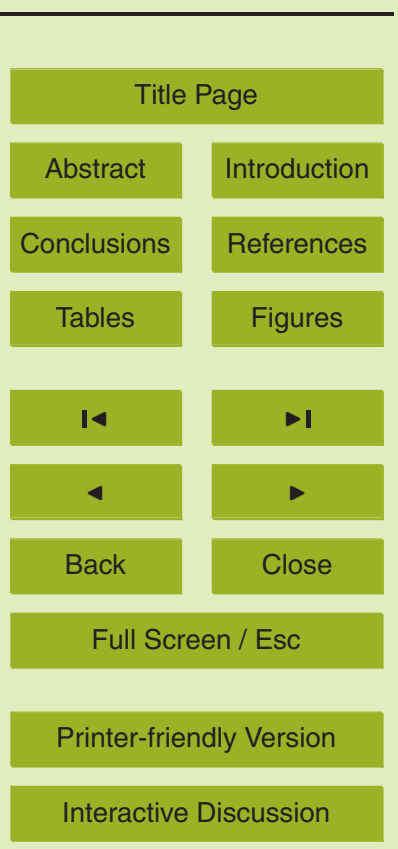

Interactive Discussion 
Rosenfeld, M., Yam, R., Shemesh, A., and Loya, Y.: Implication of water depth on stable isotope composition and skeletal density banding patterns in a Porites lutea colony: results from a long-term translocation experiment, Coral Reefs, 22, 337-345, 2003.

Rosenfeld, M., Shemesh, A., Yam, R., Sakai, K., and Loya, Y.: Impact of the 1998 bleaching event on $\delta^{18}$ O records of Okinawa corals, Mar. Ecol. Prog. Ser., 314, 127-133, 2006.

Silverman, J., Lazar, B., and Erez, J.: Monitoring the health of coral reef ecosystems using community metabolism, in: Coral Health and Disease, edited by: Rosenberg, E. and Loya, Y. (Eds.), Springer-Verlag, Berlin Heidelberg, Germany, 367-373, 2004.

Swart, P. K.: Carbon and oxygen isotope fractionation in scleractinian corals - a review, EarthSci. Rev., 19, 51-80, 1983.

Wielgus, J. and Levy, O.: Differences in photosynthetic activity between coral sections infested and not infested by boring spionid polychaetes, J. Mar. Biol. Assoc. UK, 86, 727-728, 2006.

\section{BGD}

$7,7657-7672,2010$

\section{Stable isotopes in corals under eutrophication}

O. Levy et al.

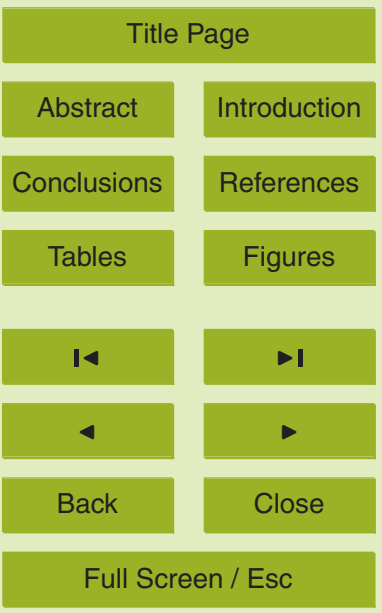

Printer-friendly Version

Interactive Discussion 


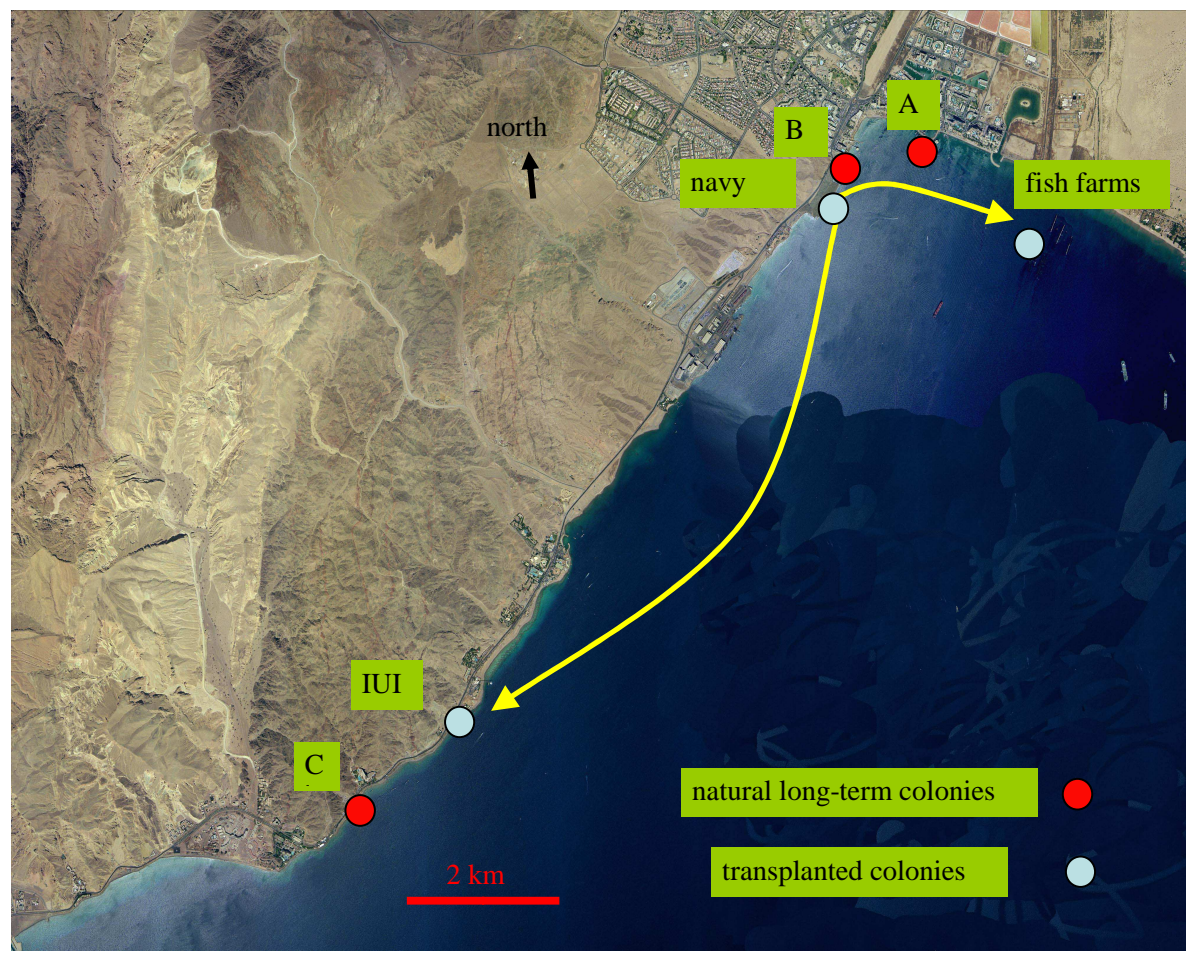

BGD

$7,7657-7672,2010$

Stable isotopes in corals under eutrophication

O. Levy et al.

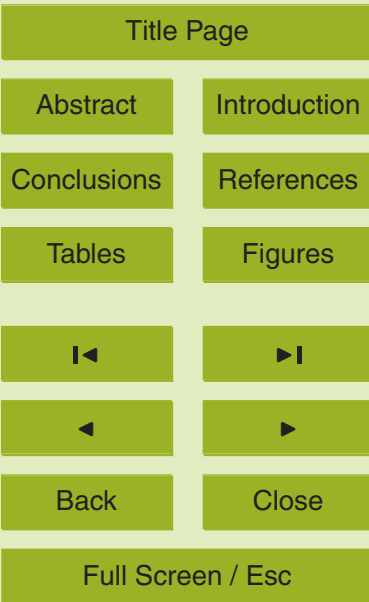

Fig. 1. The study site at the northern tip of Eilat, Gulf of Aqaba. In red: long cores, drilled from un-manipulated coral colonies at the northern and southern part of the study area (5-7 m depth). In blue: coral colonies transplanted from the navy base to under the fish cages and to the reference site in front of the IUI laboratory (20 m depth). Core A is located close to the north beach in front of the hotels line $\left(29^{\circ} 32^{\prime} 54.88^{\prime \prime} \mathrm{N}, 34^{\circ} 57^{\prime} 25.54^{\prime \prime} \mathrm{E}\right)$, core B is close to the navy harbor $\left(29^{\circ} 32^{\prime} 50.20^{\prime \prime} \mathrm{N}, 34^{\circ} 57^{\prime} 16.45^{\prime \prime} \mathrm{E}\right)$, core $\mathrm{C}$ is located, southwest of the fish farms $\left(29^{\circ} 29^{\prime} 48.62^{\prime \prime} \mathrm{N}, 34^{\circ} 54^{\prime} 41.81^{\prime \prime} \mathrm{E}\right)$.

Interactive Discussion 

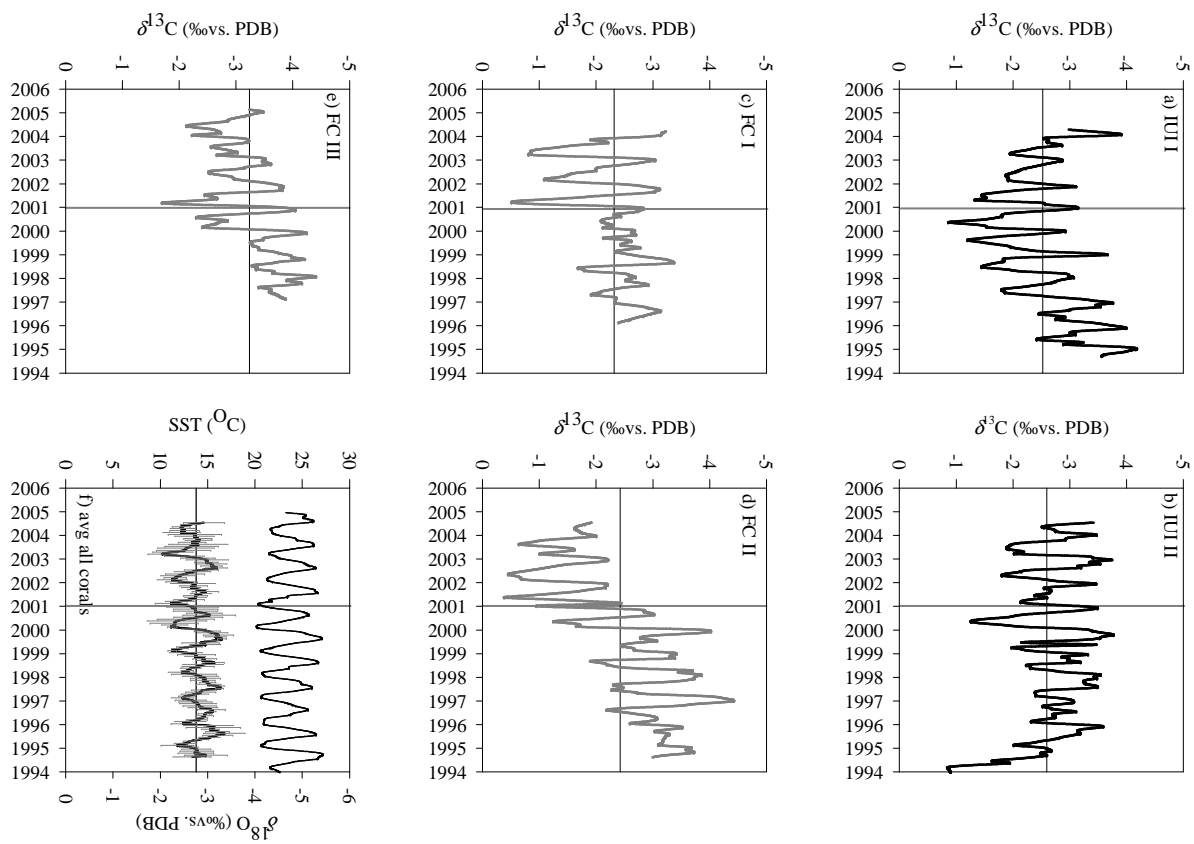

Fig. 2. $\delta^{13} \mathrm{C}$ and $\delta^{18} \mathrm{O}$ compositions of the transplanted coral colonies. The gray line represents the alizarin stain line imprinted in the skeleton in January 2001 during the transplantation procedure. $(\mathbf{a}, \mathbf{b})$ Corals transplanted to the IUI reference site; $(\mathbf{c}-\mathbf{e})$ corals transplanted near the fish farm area; (f) average skeletal $\delta^{18} \mathrm{O}$ since 1994 (black line) of transplanted corals (FC and IUI) compared with monthly SSTs (top black line), ( $n=5$ colonies), (black line represents the mean value).

\section{BGD}

$7,7657-7672,2010$

Stable isotopes in corals under eutrophication

O. Levy et al.

\section{Title Page}

Abstract

Introduction

Conclusions

References

Tables

Figures

14

$>$ I

4

Back

Close

\section{Full Screen / Esc}

Printer-friendly Version

Interactive Discussion 

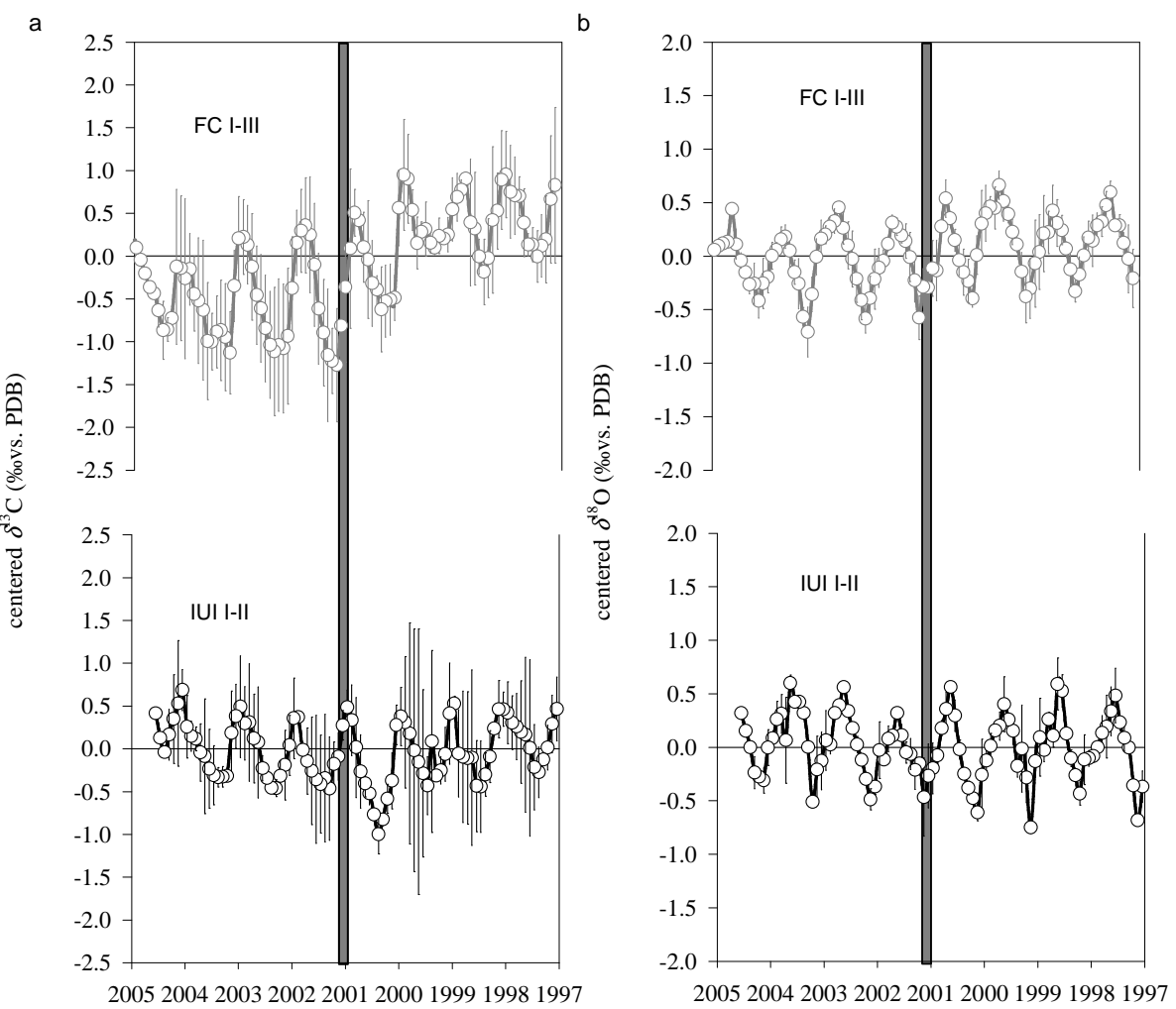

\section{BGD}

$7,7657-7672,2010$

\section{Stable isotopes in corals under eutrophication}

O. Levy et al.

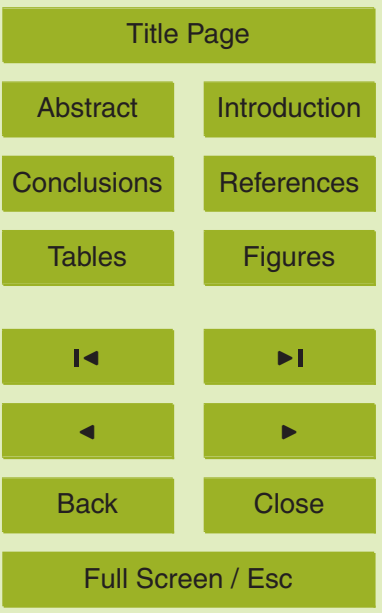

Fig. 3. Centered values (mean $\pm S D$ ) of oxygen and carbon isotopes from IUI and FC colonies before and after transplantation in 2001, alizarin stain line is marked in gray. (a, b) Top graphs represents the FC $(\mathbf{c}, \mathbf{d})$ represents IUI.

Printer-friendly Version

Interactive Discussion 

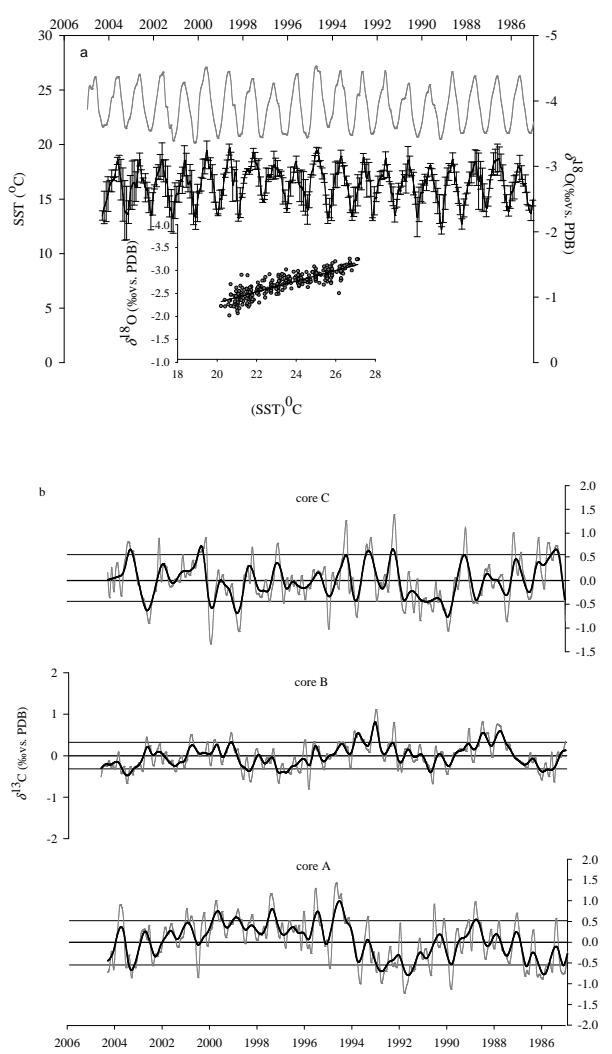

Fig. 4. Monthly variability in skeletal $\delta^{18} \mathrm{O}$ and $\delta^{13} \mathrm{C}$ averaged over three long Porites sp. coral cores retrieved from north to south in the Gulf of Aqaba, Eilat. (a) $\delta^{18} \mathrm{O}$ (mean $\pm \mathrm{SD}$ ) since 1985 compared with monthly SSTs (gray line). The correlation $\left(r^{2}=0.74\right)$ between SST and $\delta^{18} \mathrm{O}$ after averaging the three corals since 1985 . The slope is $-0.116 \%$ oper ${ }^{\circ} \mathrm{C}$. (b) Monthly anomalies of $\delta^{13} \mathrm{C}$ from core $\mathrm{C}$ : core $\mathrm{B}$; core $\mathrm{A}$, coral cores (black line representing moving average 5 points).
BGD

$7,7657-7672,2010$

Stable isotopes in corals under eutrophication

O. Levy et al.

\section{Title Page}

Abstract Introduction

Conclusions References

Tables

Figures

14

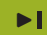

4

Back

Close

\section{Full Screen / Esc}

Printer-friendly Version

Interactive Discussion 


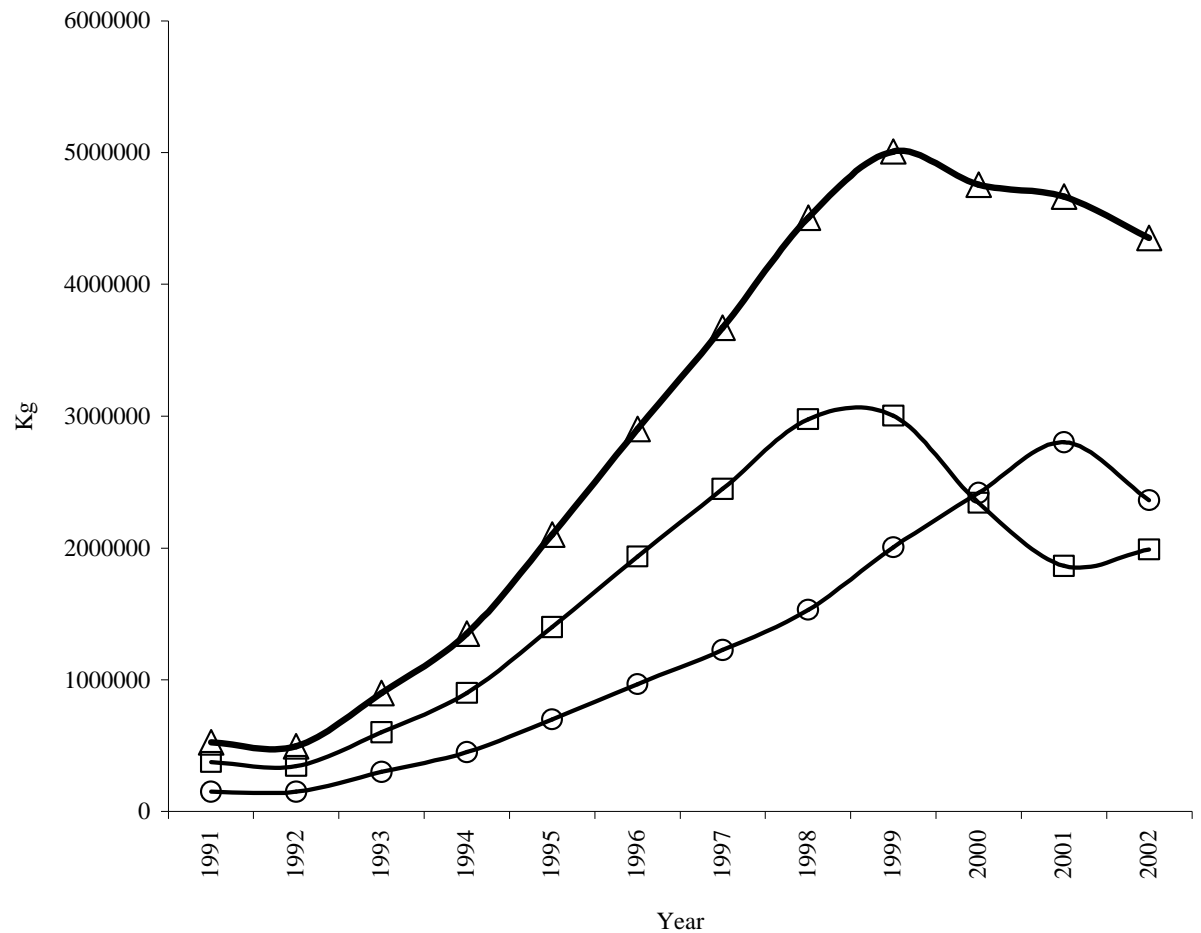

Fig. 5. Net feeding and nutrient discharge by the fish farming over the years calculating from the feeding versus the yield growth of the fishes in $\mathrm{kg}$. Open triangles represents feed in $\mathrm{kg}$, open cycles represents yield in $\mathrm{kg}$, and open squares represents discharge in $\mathrm{kg}$.

\section{BGD}

$7,7657-7672,2010$

\section{Stable isotopes in corals under eutrophication}
O. Levy et al.

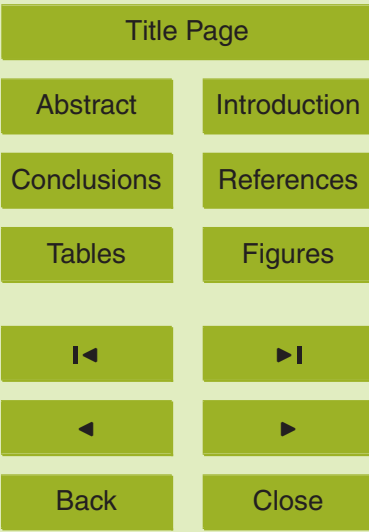

Full Screen / Esc

Printer-friendly Version

Interactive Discussion 